\title{
Changes of cytotoxicity of Ti-6Al-4V alloy made by DMLS technology as effect of the shot peening
}

\author{
Remigiusz Żebrowski ${ }^{1, A-D \oplus}$, Mariusz Walczak ${ }^{2, F}$, Kazimierz Drozd ${ }^{2, E \oplus}$, Mirosław Jerzy Jarosz ${ }^{3, E \oplus ~}$ \\ ${ }^{1}$ Department of General Burgery, St. John of Dukla Centre Oncology for Lublin Region, Poland \\ ${ }^{2}$ Department of Materials Engineering, Faculty of Mechanical Engineering, Lublin University of Technology, Lublin, \\ Poland \\ ${ }^{3}$ Faculty of Human Sciences, University of Economics and Innovation, Lublin, Poland \\ A - Research concept and design, B - Collection and/or assembly of data, C - Data analysis and interpretation, \\ $D$ - Writing the article, $E$ - Critical revision of the article, $F$ - Final approval of article
} Żebrowski R, Walczak M, Drozd K, Jarosz MJ. Changes of cytotoxicity of Ti-6Al-4V alloy made by DMLS technology as effect of the shot
peening. Ann Agric Environ Med. 2020; 27(4): 706-712. doi: $10.26444 /$ aaem/116386

\begin{abstract}
Objective. The aim the study was to investigate the impact of the shot peening process on the condition of the surface layer and biological properties of titanium alloy produced by means of the Direct Metal Laser Sintering (DMLS) method.

Materials and method. Specimens were prepared by the EOSINT M280 metal sintering laser system. The surfaces were subjected to the shot peening process using three different media, i.e. steel shot, nutshell granules and ceramic beads, after which they were subjected to profilometric analysis, scanning electron microscopic (SEM) observations and energy dispersive X-ray spectroscopy (EDS) tests, as well as to assessment of biological compatibility in terms of cytotoxicity (SHSY5Y cell lines).

Results. The general results obtained from the tests indicate satisfactory biocompatibility of the examined surfaces and that the impact of the shot peening process on the titanium alloy cytotoxicity is acceptable.

Conclusions. The lowest cytotoxicity was demonstrated by the surfaces modified by ceramic beads than the nutshells and the biggest steel shot correspondingly. Moreover, the shot peening process carried out by means of CrNi steel and ceramic shot caused the reduction of surface roughness when, for the surface processing by means of nutshell granules, the increase of surface roughness was observed compared with the unmodified surface of titanium alloy samples.
\end{abstract}

\section{Key words}

neuroblastoma, cytotoxicity, titanium implant, shot peening, additive manufacturing

\section{INTRODUCTION}

The scope of the most important factors contributing to the selection of metallic biomaterials encompasses the acceptability of said materials by the human body, so-called biocompatibility. The scope of biocompatibility encompasses the adaptation by living tissues, proper mechanical properties, easy forming, alloy tarnishing over time (associated with passivation) and its resistance to corrosion [1]. Low biotolerance means that application of the biomaterial may, among others, lead to the occurrence of inflammatory or allergic reactions and carcinogenic potential of corrosion products in certain cases $[2,3]$.

Generally, titanium and its alloys are recognized as materials with excellent corrosion resistance and biotolerance. They are characterized by the highest corrosion resistance from among the other metallic biomaterials. The excellent corrosion resistance characterizing titanium and its alloys in the environment of human tissues and body fluids can be explained by the self-passivation and re-passivation capability of the metal surface $[4,5]$. In special cases of cancer treatment, it is often necessary to surgically remove the infected part of an organ and its reconstruction thereafter [6]. In such cases, nonresorbable materials obtained from additive manufacturing

Address for correspondence: Kazimierz Drozd, Lublin University of Technology, Faculty of Mechanical Engineering, Poland

E-mail:k.drozd@pollub.pl

Received: 05.07.2019; accepted: 07.01.2020; first published: 22.01.2020 processes are used for the reconstruction of human body parts. Recently, there has been an intensive development of additive manufacturing technologies associated with the production of personalized implants made of Ti-6Al-4V alloy $[7,8,9]$. 3D printing technology based on metallic powders gives wide opportunities to create bone implants in the case of the necessity of replacement of a part of a bone or its reconstruction. In such cases, it is possible to design an implant by means of magnetic resonance or computer tomography, and to produce this implant by means of 3D laser sintering systems, with consideration of the smallest anatomical details.

The additive manufacturing technologies work particularly well in the case of the necessity to create an implant with a complex shape adapted to the patient's anatomic conditions, and to produce it on demand. Alternatively, the technologies may be used in the case of necessity to produce porous or cellular structures with proper mechanical strength and rigidity for implants which cannot be produced by conventional processes, e.g. casting, plastic forming or material removal methods. An example of such an element (intervertebral disc) produced by the authors in DMLS technology (Direct Metal Laser Sintering) is shown in Figure

The products obtained by the 3D printing method, even with consideration of printing process optimal parameters dedicated by DMLS systems manufacturers, are characterized by certain structural discontinuities in the surface layer, among others, unmelted powder grains, pores, etc. $[10,11]$. 
These surface effects may constitute the areas of increased intensity of metal elements release to adjacent tissues. Research reports indicate that the atoms of elements such as $\mathrm{Ti}, \mathrm{Al}$, or $\mathrm{V}$ are released from titanium alloy to the human body [12].

Simultaneously, research carried out by Vaithilingam et al. [13] demonstrated that only $\mathrm{Ti}$ and $\mathrm{Al}$ are released from implants produced by the 3D printing technique. However, the presence of vanadium as well as associated vanadium oxides, i.e. $\mathrm{V}_{2} \mathrm{O}_{3}$ and $\mathrm{V}_{2} \mathrm{O}_{5}$ occurring in the case of titanium implants produced by means of conventional techniques, has been not observed. Toxic vanadium oxides potentially accumulating in kidneys, liver, spleen, and lungs, as well as in adipose tissue and heart, seem to be particularly hazardous, but osseous tissues and teeth are the principal stores for vanadium absorbed by the body [13].

In accordance with clinical studies [14], metallosis associated with penetration of wear debris created in the course of prosthesis use, as well as osteolysis and aseptic loosening secondary to wear debris belong, among others, to the reasons for unsuccessful applications of titanium implants. Analysis of damage to hip and knee joints demonstrated that an excessive release of friction wear products was accompanied by an increased level of metal ions in the whole blood and serum of patients $[15,16,17]$. Increased levels of Ti ions in the blood of patients with spine implants have been described in studies $[18,19,20]$. However, Wang et al. [21] detected an increased concentration of Ti ions in tissues surrounding spine implants almost 50 times higher than the normal level. There is evidence that the biocompatibility of an implant, to a large extent depends on surface roughness and morphology [22, 23].

Available publications indicate that the problem of aseptic loosening constitutes almost $75 \%$ of revision surgeries [14, $24,25]$. The authors emphasize that the correct selection of materials for implants or increased resistance of load bearing surfaces to wear can reduce the problem and improve the durability of applied prostheses [14]. Tribological research carried out by Żebrowski and Walczak demonstrate that printed 3D surfaces made of Ti-6Al-4V alloy and subjected to shot peening by means of steel shot and ceramic beads increase the resistance to abrasive wear in simulated in vitro conditions [26]. Furthermore, DMLS technology itself leads to the creation of residual stresses in the products. Therefore, in case of such products, it is favourable to apply the shot peening process to increase the strength of metallic elements as a result of surface layer reinforcement [27]. In accordance with research carried out by authors presented in earlier studies, as a result of shot peening, shot grains penetrate (drive) into subsurface layer and, with the exception of improvement of mechanical properties, may slightly deteriorate the corrosion resistance of the modified products. Furthermore, the residuals of shot peening medium in the surface layer may contribute to elements ions release to adjacent tissues, and consequently to toxicity $[28,29]$.

There is a view that the local unfavourable reactions of tissue are associated with elements being released mainly due to the fact that the local tissue is exposed to significantly higher concentrations of released metallic ions [30, 31]. Furthermore, the degree of cytotoxicity, and consequently the biocompatibility of metallic alloys, is associated with the alloy composition as well as with elements released from the alloy to the surrounding environment - (nutrient medium) or body tissues.
Therefore, the purpose of the present research was to examine the impact of the shot peening process on the condition of the surface layer and on the cytotoxicity of titanium alloy.

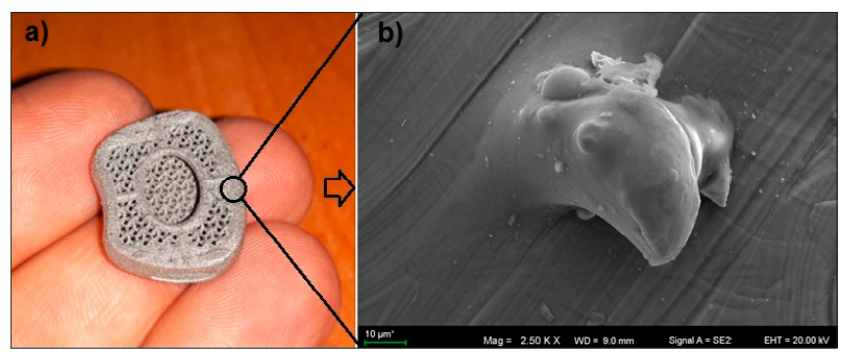

Figure 1. Titanium implant of intervertebral disc produced by DMLS technology: a) macroscopic picture, b) unmelted metal powder grain visible on the element surface (own research)

\section{MATERIALS AND METHOD}

The 24 specimens (divided into four groups of six) were made of gas atomized $\mathrm{Ti}-6 \mathrm{Al}-4 \mathrm{~V}$ alloy powder, characterized by their almost spherical shape and chemical composition which meet the requirements of the ASTM F1472 standard in the scope of maximum impurities concentration. The specimens in the shape of discs with the diameter of $12 \mathrm{~mm}$ and $7 \mathrm{~mm}$ thick were made using the DMSL technique by means of the EOSINT M280 laser metal sintering system (EOS GmbH, Germany). Among others, the essential parameters applied in the course of printing were: distance between the paths of $0.1 \mathrm{~mm}$, velocity of laser beam movement of $1,250 \mathrm{~mm} / \mathrm{s}$, thickness of melted powder layers of $30 \mu \mathrm{m}$, and applied laser beam power of $170 \mathrm{~W}$.

Outer surfaces of the specimen face in horizontal plane $\mathrm{X}-\mathrm{Y}$ have been subjected to the shot peening process on Peenmatic micro 750S equipment (IEPCO, Swiss) by means of three different media (for three different groups of samples) i.e. CrNi steel shot, nutshell granules and ceramic beads. Surface processing time was equal to 60 s and the distance between nozzle and processed surface face $\sim 25 \mathrm{~mm}$. The shot peening process was carried out under pressure of 0.4 MPa perpendicularly to the surface. According to previous publications [26,28-29], the used treating parameters allowed to prepare material with the best mechanical properties and corrosion resistant. The principal parameters of materials used in the peening process are included in Table 1.

The specimens for tests were subjected to profilometric measurements on Contour GT optical profilometers (Bruker, Germany). The measurements were carried out under 5.5 $\mathrm{X}$ magnification. Profilometric analysis (area roughness parameter - Sa) was carried out on a surface area of $25 \mathrm{~mm}^{2}$ (scanning area $-5 \mathrm{~mm} \times 5 \mathrm{~mm}$ ) using the VSI method (Vertical Scanning Interferometry). Obtained signals were processed in BrukerVision 64 software.

The characteristics of materials surface after shot peening was been obtained by a Zeiss Ultra Plus scanning electron microscope (SEM) with analytic energy dispersive X-ray spectroscopy (EDS) Bruker system with energy resolution of $123 \mathrm{eV}$.

Biocompatibility evaluation in terms of cytotoxicity was repeated three times for each one of three samples randomly selected from each of four groups (one group without surface treating and three groups after shot peening). Research was 
Table 1. Parameters of shot for shot peening

\begin{tabular}{|c|c|c|c|c|c|}
\hline Shot & \multicolumn{2}{|c|}{$\begin{array}{l}\text { Typical chemical } \\
\text { composition (\%) }\end{array}$} & $\begin{array}{l}\text { Average grain } \\
\text { size }(\mu \mathrm{m})\end{array}$ & $\begin{array}{l}\text { Grain } \\
\text { shape }\end{array}$ & Hardness \\
\hline \multirow{6}{*}{$\begin{array}{l}\text { Stainless } \\
\text { steel shot - } \\
\mathrm{CrNi}\end{array}$} & $\mathrm{Cr}$ & $16-20$ & \multirow{6}{*}{$400-900$} & \multirow{6}{*}{ spherical } & \multirow{6}{*}{$235 \mathrm{HV}$} \\
\hline & $\mathrm{Ni}$ & $7-9$ & & & \\
\hline & $\mathrm{Si}$ & $1.8-2.2$ & & & \\
\hline & $\mathrm{Mn}$ & $0.7-1.2$ & & & \\
\hline & $C$ & $0.05-0.2$ & & & \\
\hline & $\mathrm{Fe}$ & bal. & & & \\
\hline $\begin{array}{l}\text { Nutshell } \\
\text { granules }\end{array}$ & \multicolumn{2}{|c|}{$\begin{array}{l}\text { non-ferrous, organic } \\
\text { blasting media }\end{array}$} & $450-800$ & angular & $\begin{array}{c}\text { approx. } \\
\text { 2.5-3.5 Mohs }\end{array}$ \\
\hline \multirow{6}{*}{$\begin{array}{l}\text { Ceramic } \\
\text { beads }\end{array}$} & $\mathrm{ZrO}_{2}$ & 61.98 & \multirow{6}{*}{$125-250$} & \multirow{6}{*}{ spherical } & \multirow{6}{*}{$\begin{array}{c}\text { approx. 7-7.5 } \\
\text { Mohs }\end{array}$} \\
\hline & $\mathrm{SiO}_{2}^{2}$ & 27.77 & & & \\
\hline & $\mathrm{Al}_{2} \mathrm{O}_{3}$ & 4.57 & & & \\
\hline & $\mathrm{CaO}$ & 3.47 & & & \\
\hline & $\mathrm{TiO}_{2}$ & 0.34 & & & \\
\hline & $\mathrm{Fe}_{2} \mathrm{O}_{3}$ & 0.14 & & & \\
\hline
\end{tabular}

conducted in accordance with the ISO 10993-5:2009 standard using the extract test and direct contact test. In the study, human neuroblastoma SH-SY5Y (ATCC, USA) cell lines were used because it is commonly used for biocompatibility evaluation, especially for scientific neurotoxicity tests [3234]. Neuroblastoma is the most common extra-cranial solid malignant tumour of the sympathetic nervous system in children. The human SH-SY5Y cell line is a subclone of the SK-N-SH cell line which was isolated from a bone marrow of a 4-year-old female patient. SH-SY5Y cells maintain their potential for regression, which results in aggressive proliferation of these cells [34]. The cells were cultured under standard conditions: at $37^{\circ} \mathrm{C}$, in a $5 \% \mathrm{CO}_{2}$ atmosphere, in EMEM/F12 (1:1) medium (USA, ATCC), supplemented with 10 $\%$ foetal bovine serum (USA, ATCC). Prior to the experiments, all cell lines were tested for the presence of mycoplasma using LookOut ${ }^{\circledast}$ Mycoplasma PCR Detection Kit (Sigma Aldrich, USA). Morphological assessment was performed using a Nikon Eclipse Ti fluorescence, phase-contrast microscope, and NISElements Imaging Processing Software (Nikon, Tokyo, Japan).

Evaluation of cell viability in the conditioned medium allows for dynamic analysis of the interaction of the tested material with the culture medium imitating body fluids. This method allows prediction of how the test material will interact with longer contact with body fluids and how it will affect the biological response.

The tested titanium discs were placed separately in 24-well culture plate and covered with $1 \mathrm{ml}$ of supplemented medium. The plate was placed on an orbital shaker and incubated continuously in $37^{\circ} \mathrm{C}$ at $300 \mathrm{rpm}$ for 24,72 and 168 hours. The appropriate medium was incubated under analogous conditions, but without the titanium insert which was used as the control.
The cells were seeded into 96 -well plates at $3{ }^{\star} 10^{4}$ cells/well. After $24 \mathrm{~h}$ when the confluency reached $80 \%$, culture medium was aspirated and the cells were covered with conditioned medium and incubated for the next 24 hours. Cells treated with $1 \%$ Triton X-100 were used as positive control.

The viability of the cells was examined by standard MTT (the letters are inexact abbreviation for dye compound described in the next sentences of the paragraph) assay, using the MTT Cell Proliferation Assay Kit (Invitrogen, USA). In this test, the activity of mitochondrial enzymesuccinate dehydrogenase was used. In living cells this enzyme is responsible for the transformation of soluble tetrazolium salt 3-(4.5-dimethylthiazol-2-yl)-2.5-diphenyltetrazolium bromide to water-insoluble purple formazan crystals. Following $4 \mathrm{~h}$ incubation, the medium with MTT was removed, and the formed crystals were dissolved in DMSO. The solution absorbency was measured at $540 \mathrm{~nm}$, using PowerWave $^{\mathrm{nat}}$ microplate spectrophotometer (Bio-Tek Instruments, USA). The experiment was repeated three times and measurements performed in triplicate.

The cells were seeded into a 12 -well plate, where a titanium insert was placed in each well. The cultures were incubated in standard conditions and cell morphology and growth near inserts was observed for three days.

The results were analysed statistically by the STATISTICA vs. 13 application (StaftSoft, Poland). Data were calculated as mean \pm SD. To compare more than two groups, the oneway analysis of variance (ANOVA) and post hoc multiple comparisons on a basis of Tukey's HSD test were used. All parameters were considered statistically significantly different if $\mathrm{p}$ values were less than 0.05 .

\section{RESULTS}

Sa parameter was used for assessment of the machined surfaces - arithmetic average roughness size - as the most representative parameter for surfaces after shot peening $[35,36]$. On the basis of analysis of the results obtained from profilometric measurements (Fig. 2) it was possible to observe reduced surface development in the case of surfaces modified by means of steel shot and ceramic beads, compared to the reference surface (directly after printing in DMLS technology). However, it is worth mentioning that at smaller (almost three times) the average size of ceramic shot in comparison with CrNi shot, it is possible to obtain a slightly greater roughness parameter Sa. Smaller shot size leads to reduction of dent size after shot peening, but this is translated into an increased number of dents per surface unit.
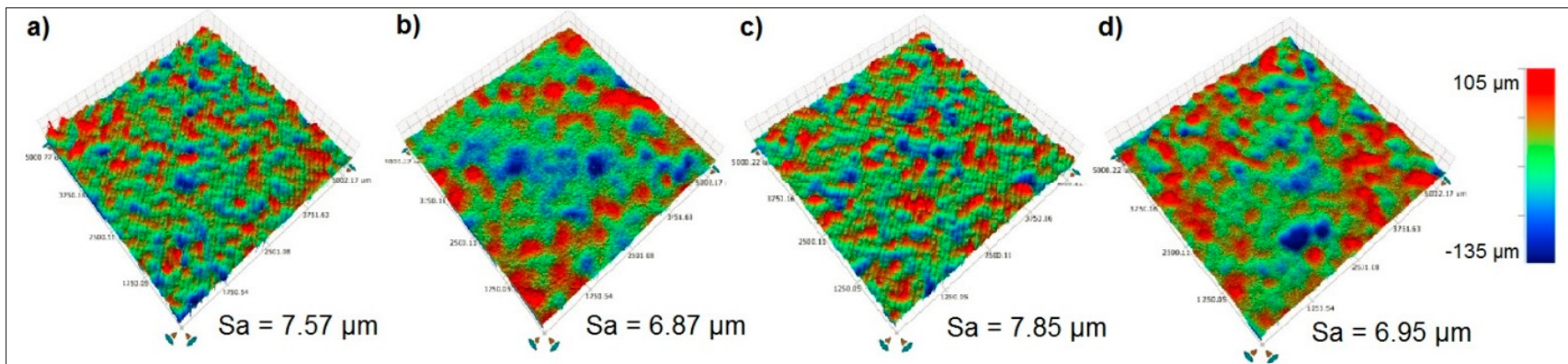

Figure 2. Roughness maps (scanning area $5 \mathrm{~mm} \times 5 \mathrm{~mm}$ ) for various surfaces modified correspondingly: a) DMLS (reference), b) steel shot CrNi, c) nutshell granules, d) ceramic beads 

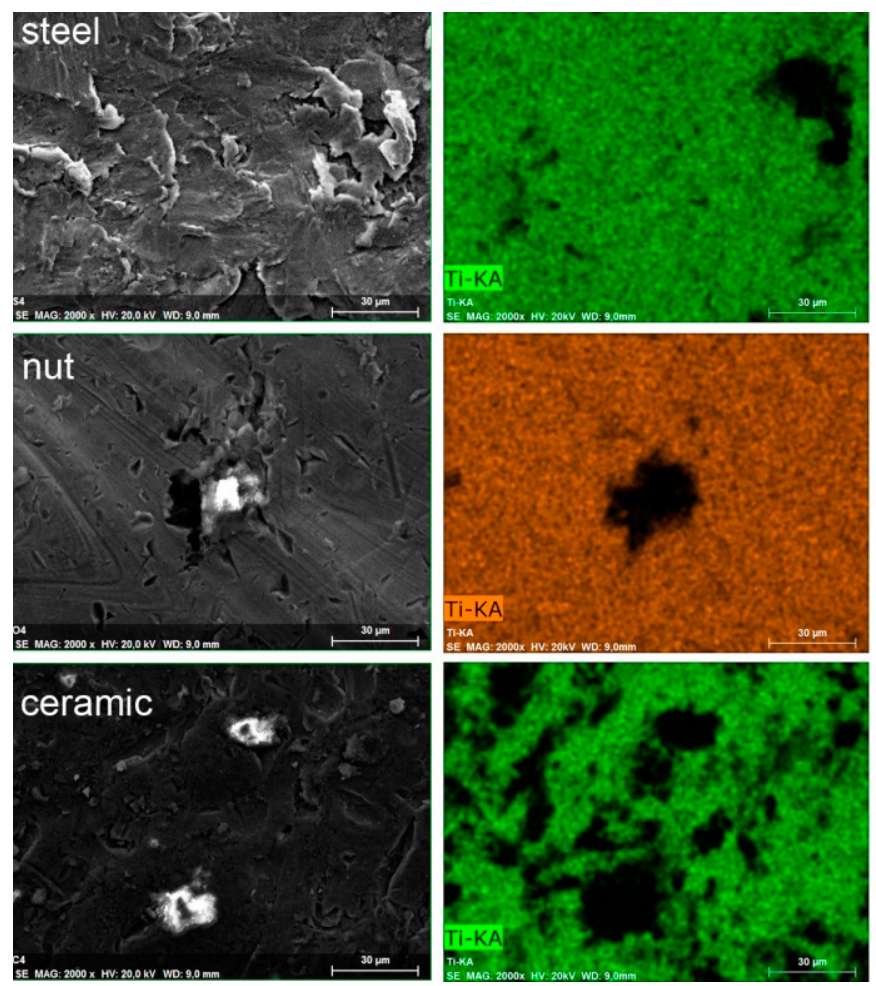
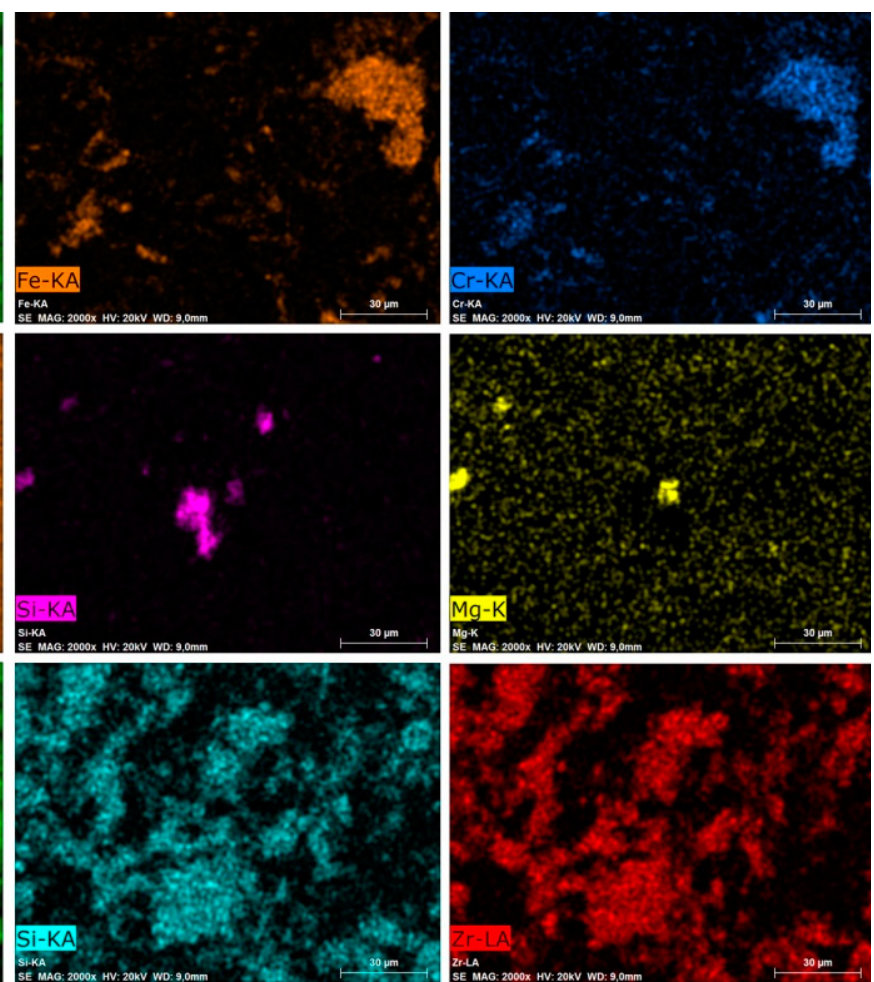

Figure 3. SEM microphotos (left column) illustrating shot inclusions on specimen surfaces and proves the inclusion of chemical elements from EDS analysis for the particular shot materials (steel in the top row; nut and ceramic in bottom row)

However, the surface treatment by means sharp-edged nutshell granules leads to an increase of roughness parameter Sa, compared with reference specimens.

Scanning electron microscopic (SEM) analysis of the surfaces after the shot peening process (Fig. 3) demonstrated the presence of shot peening medium residuals in the surface layers which are located in structural discontinuities or directly on the titanium alloy surface as the result of high kinetic energies they achieved themselves. Ti-6Al-4V alloy belongs to the group of materials with significant ductility and plasticity, as well as high reactivity which additionally contributes to penetration of shot into the surface layer, additionally modifying the surface topography.

MTT test results revealed that the $24 \mathrm{~h}$-conditioned media did not cause any toxicity against tested cells. Significant decreased cells viability was observed in cultures treated with media conditioned for $72 \mathrm{~h}$, with insert modified with steel shot and nutshell granules $(89.70 \pm 10.23$ and $92.47 \pm 3.91 \%$ of viability, respectively). Among the long-conditioned media (168h), only the surface modified with steel shot revealed toxicity (compared to DMLS) $-87.95 \pm 2.50 \%$ of cells viability (Fig. 4). The results show that the insert modified with steel shot exerted the most adverse effects on the test cells, and the effect persists over time.

It was observed that the presence of the insert inhibited proliferation of the tested cells (Fig. 5). Unexpectedly, it was observed that the cells proliferated slightly more intensely close to the insert modified with ceramic beads, as evidenced by the cell clusters after $48 \mathrm{~h}$ and $72 \mathrm{~h}$ of incubation, compared to the uniformly covered wells of the culture plate in the presence of other inserts. Except for the differences in cell density, they did not differ morphologically. The cells did not differentiate into neuronal cell types because there was no particular neurite outgrowth.

\section{DISCUSSION}

Increased shot size at constant working pressure usually leads to the reduction of roughness [36]. However, it is not unambiguous because the increase of shot size from $125 \div 250 \mu \mathrm{m}$ to $450 \mu \mathrm{m}$ in the tests caused the increase of roughness, although in the case of the size two times larger of $850 \mu \mathrm{m}$, the roughness was reduced [5]. Reduction of shot size caused the reduction of dent size after shot peening, and increased the number of dents per surface unit. These tests indicate that not only the process parameters contribute to the surface layer condition, but also primarily to the geometry of the applied shot, i.e. shot size and shape. However, in the opinion of Liu et al. [35], to achieve the most favourable deformation of the surface layer, in view of optimal combination of shot size and roughness, the shot penning of Ti- $6 \mathrm{Al}-4 \mathrm{~V}$ alloy should be carried out at lower pressures a during longer processing.

Titanium alloys are protected as a result of thin passive layer spontaneously developing on their surface. The passive layer created on surgical Ti-6Al-4V alloys is stable in body fluids solution, and rich mainly in amorphous $\mathrm{TiO}_{2}$ $[4,29,37]$. The thickness of such passive films is usually equal to a few nanometres, but they constitute a highly protective barrier between the metallic alloy surface and the aggressive environment of body fluids. Furthermore, the protective properties of the passive layer depend mainly on the chemical composition, its structure, thickness and potential defects. Therefore, higher surface roughness and inclusions originating from steel shot may reduce the corrosion resistance of medical implants, and contribute to the transport of ions through the passive film.

As a result of the shot peening process, a rough surface is created which is susceptible to corrosion in connection with destroyed areas of the passive film as a result of the shot impact 

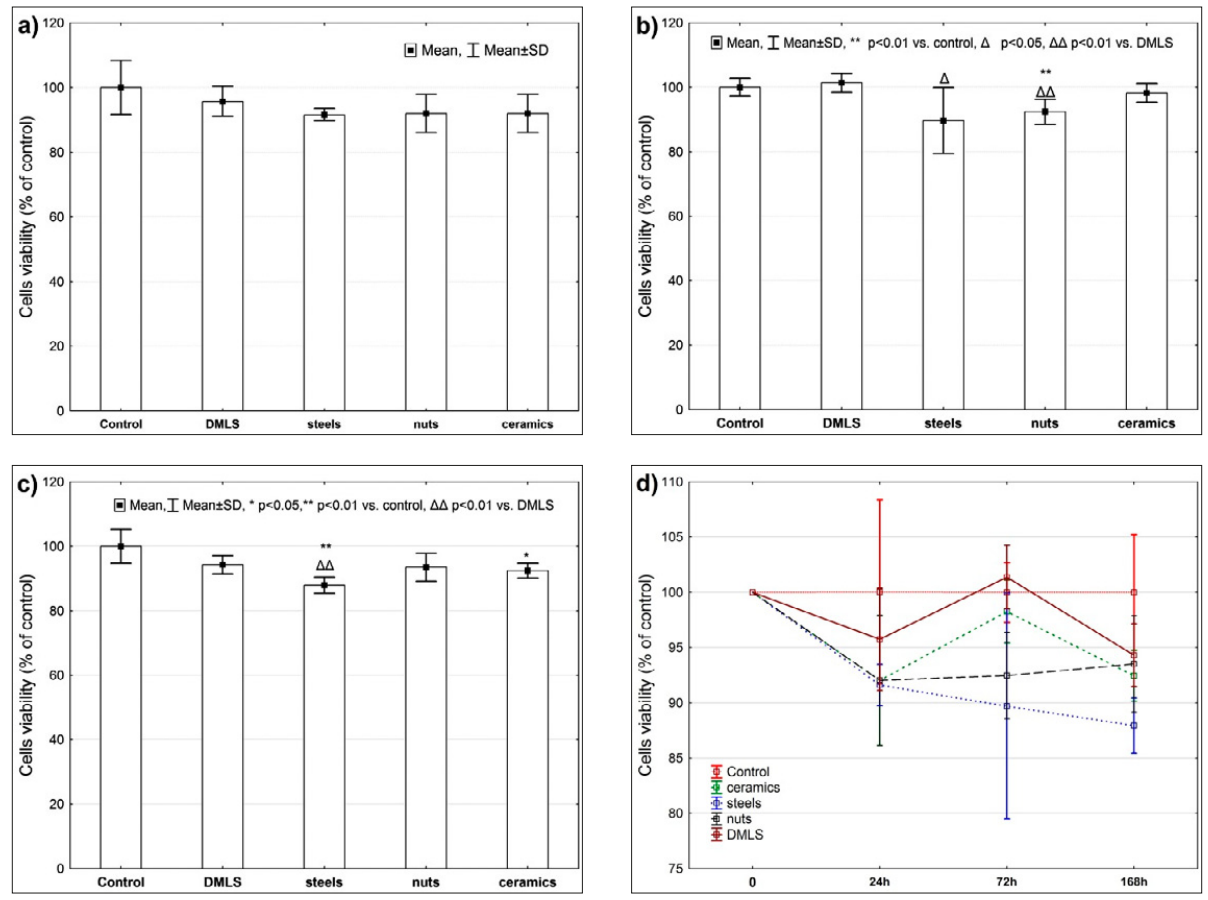

Figure 4. MTT test results for neuroblastoma cells treated with tested titanium discs extracts according to kind of disc modification for: a) $24 \mathrm{~h}$, b) $72 \mathrm{~h}$, c) $168 \mathrm{~h}$ of extraction. d) MTT test results according to time of extraction. Data expressed as \% of values obtained for control
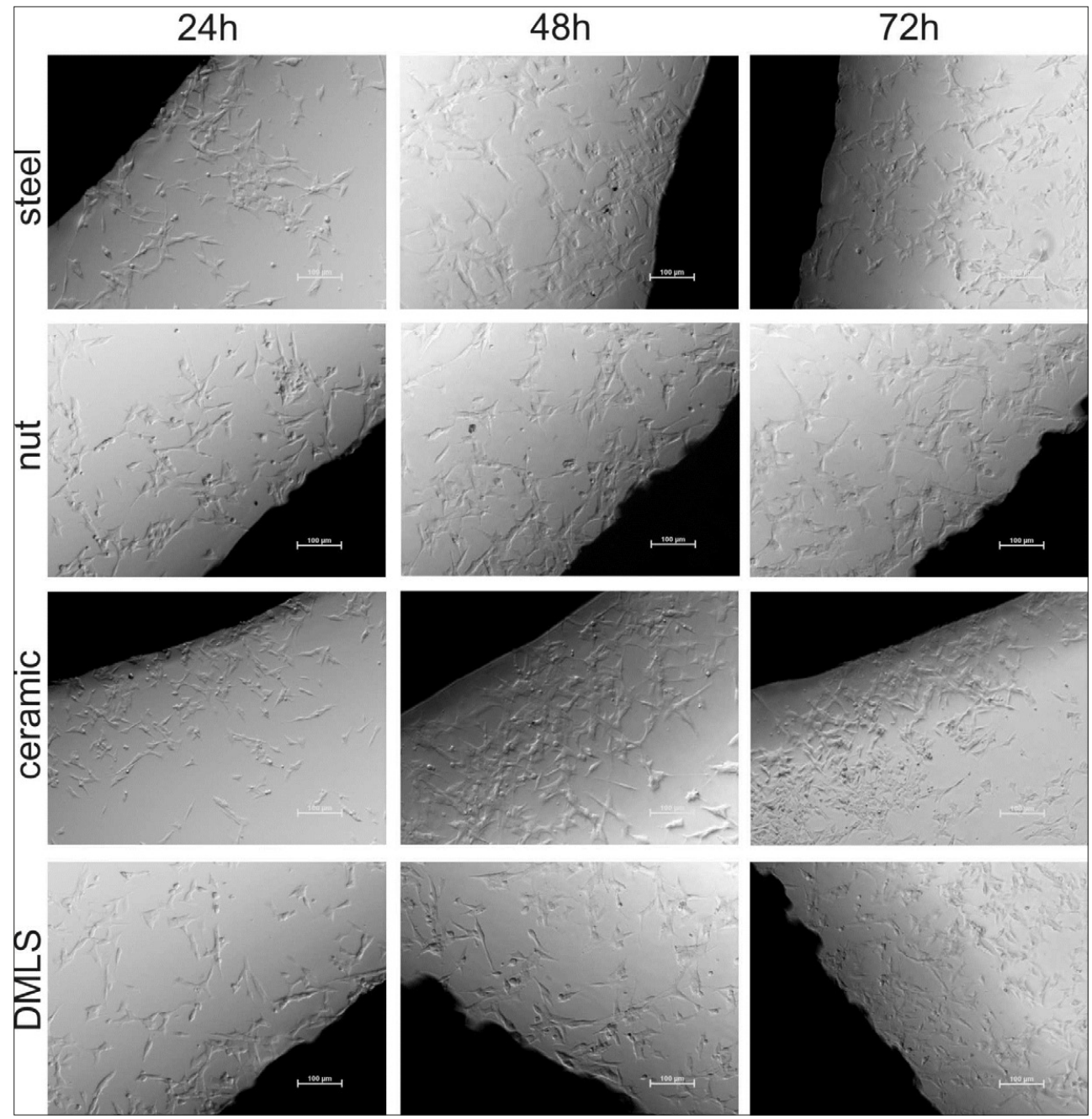

Figure 5. Cells growth and proliferation in direct contact with the examined inserts. The black areas belong to titanium specimen. 
$[28,29]$. However, Jelliti et al. [4] observed the creation of a stable passive film, and the increase of electrochemical potential on titanium specimens subjected to the shot peening process.

In accordance with literature data $[4,36,38,39]$, the plastic strain leads to nanocrystallization in the surface layer which, excepting strength increase, positively contributes to the corrosion resistance and wear. It has been suggested that the dislocation density and shot size may affect the properties of the surface layer in modified products. Simultaneously, in accordance with our own research and with literature data, as a result of the shot peening process, the shot grains may penetrate to the surface layer (depositing permanently) and modify tribology characteristics as well as corrosion resistance of the products thus modified [40,41, 42]. Furthermore, such phenomenon, except corrosive changes, may cause accelerated metal ions release and contribute to the implant cytotoxicity $[43,44,45]$.

Arparicio et al. found that chemical changes after the shot peening process translate into the corrosion resistance of dental implants. Nevertheless, the changes that occurred after modification of the surface layer meet proper criteria in the scope of possibility for applying such modified materials as dental implants [41]. Although there are many publications informing about the positive effects of the modification of materials used as implants by means of steel and ceramic shot, no literature data are available for nutshell suitability. Our examinations in the scope of cytotoxicity indicate that, except for used ceramic shot, which is recognized as a bio-neutral material, quite favourable results have also been also obtained for surfaces modified by means of organic nutshells. Steel shot is rich in $\mathrm{Cr}$ and $\mathrm{Ni}$ and, taking into account the corrosion resistance and potential release of carcinogenic metal ions, it should be rather limited to the processing of materials used mainly as medical instrumentation, than for the surface modification of implants. Although the surfaces modified with steel shot observed during the MTT test (Fig. 4) demonstrated the worst cells viability from among the tested specimens $(87.95 \pm 2.50 \%$ after $168 \mathrm{~h}$ of extraction), results of the tests generally indicate the satisfactory biocompatibility of the tested surfaces.

The surface roughness enhances osseointegration of the titanium implants through increased osteoblast differentiation while osteoblast proliferation remains greater on smooth titanium [46]. Havlikova et al. [47] found that the proper condition of the surface layer finished by means of shot peening introduces favourable mechanical properties and enhanced osteoblast proliferation. Moreover, the finished surface layer supported early osteogenic cell differentiation, manifested by a high expression of collagen type I. Favourable biological properties of specimens obtained from $3 \mathrm{D}$ printing subjected to the shot peening process have also been demonstrated by Benedetti et al. [38]. Titanium specimens were tested in terms of cells growth at different times. It has been demonstrated that specimens with various surface roughness (after electropolishing and shot peening process) demonstrate a quite similar favourable behaviour in the scope of cells growth and proliferation. In the presented tests, also the influence diversification of surface development condition (Fig. 2) on the biocompatibility was not as high as the impact of the type of shot peening medium applied.

Also, the research of 3T3 cell-cytotoxicity on the surface of Ti-6Al-4V obtained directly from 3D printing and subjected to polishing, did not indicate to any significant differences in cells behaviour [13]. The test carried out during the period of 7 days demonstrated that the cells were living on both surfaces, and that there was practically no dissolution of metals ions from the specimens in culture medium.

Tuomi et al. [48] emphasize the necessity of modification of surface layer of implants after 3D printing. Although the surface obtained directly after 3D printing increases the adherence of a tissue to the implant (higher roughness), the surface defects may constitute the areas with reduced fatigue strength, particularly in the case of implants under dynamic load. Nevertheless, the high viability of L929 cells after an incubation period of $24 \mathrm{~h}$ has been found in extracts in the case of non-processed and polished DMLS specimens.

\section{CONCLUSIONS}

The following conclusions have been drawn on the basis of authors' own tests:

- results obtained from the MTT test indicate the satisfactory biocompatibility of the tested surfaces, and the impact of the shot peening process on cytotoxicity of titanium alloy is acceptable;

- the lowest cytotoxicity was demonstrated by the surfaces modified by means of ceramic beads than nutshells and the biggest steel shot correspondingly;

- the shot peening process carried out with $\mathrm{CrNi}$ steel and ceramic shot caused the reduction of surface roughness in relation to the unmodified surface; however, in the case of surface processing with nutshell granules, an increase of surface roughness is observed in comparison with the reference surface;

- SEM and EDS analysis of the surface layer in specimens after the shot peening process demonstrated the presence of shot fragments left by the shot peening medium, which affected the biocompatibility of the tested surfaces.

\section{REFERENCES}

1. Walczak M. Influence of the selected technological processes on durability of metal-ceramic systems used in dental prosthetics. Lublin University of Technology Publishers, 2014.

2. Elshahawy W, Watanabe I. Biocompatibility of dental alloys used in fixed prosthodontics. Tanta Dental J. 2014; 11(2): 150-159. https://doi. org/10.1016/j.tdj.2014.07.005

3. El-Hadad S, Safwat EM, Sharaf NF. In-vitro and in-vivo, cytotoxicity evaluation of cast functionally graded biomaterials for dental implantology. Mater Sci Eng C Mater Biol Appl. 2018; 93(1): 987-995. https://doi.org/10.1016/j.msec.2018.09.003

4. Jelliti S, Richard C, Retraint D, Roland T, Chemkhi M, Demangel C. Effect of surface nanocrystallization on the corrosion behavior of $\mathrm{Ti}$ 6Al-4V titanium alloy. Surf Coat Technol. 2013; 224: 82-87. https:// doi.org/10.1016/j.surfcoat.2013.02.052

5. Ahmed AA, Mhaede M, Wollmann M, Wagner L. Effect of micro shot peening on the mechanical properties and corrosion behavior of two microstructure Ti-6Al-4V alloy. Appl Surf Sci. 2016; 363: 50-58. https:// doi.org/10.1016/j.apsusc.2015.12.019

6. Mikami T, Miyata K, Komatsu K, Yamashita K, Wanibuchia M, Mikuni N. Exposure of titanium implants after cranioplasty: A matter of longterm consequences. Interdisciplinary Neurosurgery: Adv Tech Case Man. 2017; 8: 64-67. https://doi.org/10.1016/j.inat.2017.01.015

7. Harun WSW, Manam NS, Kamariah MSIN, et al. A review of powdered additive manufacturing techniques for Ti-6Al-4V biomedical applications. Powder Techn. 2018; 331: 74-97. https://doi.org/10.1016/j. powtec.2018.03.010

8. Javaid M, Haleem A. Current status and challenges of Additive manufacturing in orthopaedics: An overview. J Clin Orthop Trauma. 2019; 10(2): 380-386. https://doi.org/10.1016/j.jcot.2018.05.008 
9. Bose S, Ke D, Sahasrabudhe H, Bandyopadhyay A. Additive manufacturing of biomaterials. Progr Mater Sci. 2018; 93: 45-111. https://doi.org/10.1016/j.pmatsci.2017.08.003

10. Mutua J, Nakata S, Onda T, Chen Z-Ch. Optimization of selective laser melting parameters and influence of post heat treatment on microstructure and mechanical properties of maraging steel. Mater Design. 2018; 139: 486-497.https://doi.org/10.1016/j.matdes.2017.11.042

11. Molaei R, Fatemi A. Fatigue Design with Additive Manufactured Metals: Issues to Consider and Perspective for Future Research. Proced Eng. 2018; 213: 5-16. https://doi.org/10.1016/j.proeng.2018.02.002

12. Szewczenko J, Walke W, Nowinska K, Marciniak J, Corrosion resistance of Ti-6Al-4V alloy after diverse surface treatments, Materialwissenschaft und Werkstofftechnik. 2010; 41(5): 360-371. https://doi.org/10.1002/ mawe. 201000610

13. Vaithilingam J, Prina E, Goodridge RD, Hague RJM, Edmondson S, Rose FRAJ, et al. Surface chemistry of Ti6Al4V components fabricated using selective laser melting for biomedical applications, Mater Sci Eng C Mater Biol Appl. 2016; 67: 294-303. https://doi.org/10.1016/j. msec.2016.05.054

14. Murali R, Bonar F, Kirsh G, Walter WK, Walter WL. Osteolysis in Third-Generation Alumina Ceramic-on-Ceramic Hip Bearings With Severe Impingement and Titanium Metallosis. J Arthroplasty 2008; 23(8): 13-19. https://doi.org/10.1016/j.arth.2007.10.020

15. Lukina E, Laka A, Kollerov M, Sampiev M, Mason P, Wagstaff P, et al. Metal concentrations in the blood and tissues after implantation of titanium growth guidance sliding instrumentation. Spine J. 2016; 16(3): 380-388. https://doi.org/10.1016/j.spinee.2015.11.040

16. Hart A, Sabah S, Bandi A, Maggiore P, Tarassoli P, Sampson B, et al. Sensitivity and specificity of blood cobalt and chromium metal ions for predicting failure of metal-on-metal hip replacement. J Bone Joint Surg Br. 2011; 93(10): 1308-1313. https://doi.org/10.1302/0301620X.93B10.26249

17. Jacobs JJ, Silverton C, Hallab NJ. Metal release and excretion from cement less titanium alloy total knee replacements. Clin Orthop Relat Res. 1999; 358: 173-180.

18. Cundy T, Antoniou G, Sutherland L, Cundy P. Serum titanium, niobium, and aluminum levels after instrumented spinal arthrodesis in children. Spine. 2013; 38(7): 564-570. https://doi.org/10.1097/ BRS.0b013e3182741961

19. Kasai Y, Iida R, Uchida A. Metal concentrations in the serum and hair of patients with titanium alloy spinal implants. Spine. 2003; 28(12) 1320-1326. https://doi.org/10.1097/01.BRS.0000065482.41115.B4

20. Richardson TD, Pineda SJ, Strenge KB, Van Fleet TA, MacGregor M, Milbrandt JC, et al. Serum titanium levels after instrumented spinal arthrodesis. Spine. 2008; 33(7): 792-796. https://doi.org/10.1097/ BRS.0b013e318169574d

21. Wang JC, Warren D, Harvinder S, Harvinder S., Foster B, Sunita B, et al. Metal debris from titanium spinal implants. Spine. 1999; 24(9): 899-903.

22. Castner DG, Ratner BD, Biomedical surface science: foundations to frontiers, Surf Sci. 2002; 500(1-3): 28-60. https://doi.org/10.1016/S00396028(01)01587-4

23. Paital SR, Dahotre NB. Calcium phosphate coatings for bio-implant applications: materials, performance factors, and methodologies, Mater Sci Eng R Rep. 2009; 66(1-3): 1-70. https://doi.org/10.1016/j. mser.2009.05.001

24. Santavirta S, Bohler M, Harris W, Konttinen YT, Lappalainen $\mathrm{R}$, Muratoglu $\mathrm{O}$, et al. Alternative materials to improve total hip replacement tribology. Acta Orthop Scand 2003; 74(4): 380-388.

25. Tipper J, Hatton A, Nevelos J, Ingham E, Doyle C, Streicher R, et al. Alumina-alumina artificial hip joints: Part II. Characterization of the wear debris from in vitro hip joint simulations. Biomaterials 2002; 23(16): 3441-3448. https://doi.org/10.1016/S0142-9612(02)00048-0

26. Żebrowski R, Walczak M, Effect of the shop peening on surface properties and tribological performance of Ti-6Al-4V alloy produced by means of DMLS technology, Arch Metall Mater. 2019; 64(1): 377-386. https://doi.org/10.24425/amm.2019.126263

27. Dai S, Zhu Y, Huang Z, Microstructure evolution and strengthening mechanisms of pure titanium with nano-structured surface obtained by high energy shot peening. Vacuum. 2016; 125: 215-221. https://doi. org/10.1016/j.vacuum.2016.01.001

28. Żebrowski R, Walczak M, Klepka T, Pasierbiewicz K, Effect of the shot peening on surface properties of Ti-6Al-4V alloy produced by means of DMLS technology. Eksploat i Niezawodnosc - Maintenance and Reliability. 2019; 21(1): 46-53. http://dx.doi.org/10.17531/ein.2019.1.6

29. Żebrowski R, Walczak M. The effect of shot peening on the corrosion behaviour of Ti-6Al-4V alloy made by DMLS. Adv Mat Sci. 2018; 18(3): 43-54. https://doi.org/10.1515/adms-2017-0040
30. Wataha JC. Biocompatibility of dental casting alloys: a review. J Prosthet Dent. 2000; 83(2): 223-234. https://doi.org/10.1016/S00223913(00)80016-5

31. Al-Hiyasat AS, Darmani H. The effects of recasting on the cytotoxicity of base metal alloys. J Prosthet Dent. 2005; 93(2): 158-163. https://doi. org/10.1016/j.prosdent.2004.11.009

32. Pallavicini P, Cabrini E, Cavallaro G, Chirico G, Collini M, D'Alfonso $\mathrm{L}$, et al. A comparative study of in-vitro biocompatibility and of their interaction with SH-SY5Y neuroblastoma cells. J Inorg Biochem. 2015; 151: 123-31. doi: 10.1016/j.jinorgbio.2015.05.002

33. Ciofani G, Raffa V, Vittorio O, Cuschieri A, Pizzorusso T, Costa M, Bardi $G$. In vitro and in vivo biocompatibility testing of functionalized carbon nanotubes. Methods Mol Biol. 2010; 625: 67-83. doi: 10.1007/978-160761-579-8_7

34. Teppola H, Sarkanen JR, Jalonen TO, Linne ML. Morphological Differentiation Towards Neuronal Phenotype of SH-SY5Y Neuroblastoma Cells by Estradiol, Retinoic Acid and Cholesterol. Neurochem Res. 2016; 41(4): 731-747. https://doi.org/10.1007/s11064015-1743-6

35. Liu YG, Li MQ, Liu HJ. Nanostructure and surface roughness in the processed surface layer of Ti-6Al-4V via shot peening. Mater Charact. 2017; 123: 83-90. https://doi.org/10.1016/j.matchar.2016.11.020

36. Ganesh BKC, Sha W, Ramanaiah N, Krishnaiah A. Effect of shot peening on sliding wear and tensile behavior of titanium implant alloys. Mater Design. 2014; 56: 480-486. https://doi.org/10.1016/j. matdes.2013.11.052

37. Tąta A., Szkudlarek A, Pacek J, Molenda M, Proniewicz E. Peptides of human body fluids as sensors of corrosion of titanium to titanium dioxide. SERS application. Appl Surf Sci. 2019; 473: 107-120. https:// doi.org/10.1016/j.apsusc.2018.12.158

38. Benedetti M, Torresani E, Leoni M, Fontanari V, Bandini M, Pederzolli $\mathrm{C}$, et al. The effect of post-sintering treatments on the fatigue and biological behavior of Ti-6Al-4V ELI parts made by selective laser melting. J Mech Behav Biomed Mater. 2017; 71: 295-306. https://doi. org/10.1016/j.jmbbm.2017.03.024

39. Unal O, Karaoglanli AC, Varol R, Kobayashi A. Microstructure evolution and mechanical behavior of severe shot peened commercially pure titanium. Vacuum. 2014; 110: 202-206. https://doi.org/10.1016/j. vacuum.2014.08.004

40. Kameyama Y, Komotori J. Effect of micro ploughing during fine particle peening process on the microstructure of metallic materials. J Mater Process Tech. 2009; 209(20): 6146-6155. https://doi.org/10.1016/j. jmatprotec.2009.08.010

41. Aparicio C, Gil FJ, Fonseca C, Barbosa M, Planell JA. Corrosion behaviour of commercially pure titanium shot blasted with different materials and sizes of shot particles for dental implant applications. Biomaterials 2003; 24(2): 263-273. https://doi.org/10.1016/S01429612(02)00314-9

42. Velasco-Ortega E, Alfonso-Rodríguez CA, Monsalve-Guil L, et al. Relevant aspects in the surface properties in titanium dental implants for the cellular viability. Mater Sci Eng C Mater Biol Appl. 2016; 64: 1-10. https://doi.org/10.1016/j.msec.2016.03.049

43. Kim WG, Ahn KH, Jeong YH, Vang MS, Choe HC. Surface Characteristics and Cell Proliferation of Mechanical Sandblasted Ti30Ta-xNb Surface. Proced Engin. 2011; 10: 2399-2404. https://doi. org/10.1016/j.proeng.2011.04.395

44. Wang H-Y, Zhu R-F, Lu Y-P, et al. Preparation and properties of plasma electrolytic oxidation coating on sandblasted pure titanium by a combination treatment. Mater Sci Eng C Mater Biol Appl. 2014; 42(1): 657-664. https://doi.org/10.1016/j.msec.2014.06.005

45. Wei D, Du Q, Guo S, et al. Structures, bonding strength and in vitro bioactivity and cytotoxicity of electrochemically deposited bioactive nano-brushite coating/TiO2 nanotubes composited films on titanium. Surf Coat Technol. 2018; 340: 93-102. https://doi.org/10.1016/j. surfcoat.2018.02.023

46. Lee EM, Smith K, Gall K, Boyan BD, Schwartz Z. Change in surface roughness by dynamic shape-memory acrylate networks enhances osteoblast differentiation. Biomaterials 2016; 110: 34-44. https://doi. org/10.1016/j.biomaterials.2016.08.004

47. Havlikova J, Strasky J, Vandrovcova M, et al. Innovative surface modification of Ti-6Al-4V alloy with a positive effect on osteoblast proliferation and fatigue performance. Mater Sci Eng C Mater Biol Appl. 2014; 39: 371-379. https://doi.org/10.1016/j.msec.2014.03.024

48. Tuomi JT, Björkstrand RV, Pernu ML, Salmi MVJ, Huotilainen EI, Wolff $\mathrm{JEH}$, et al. In vitro cytotoxicity and surface topography evaluation of additive manufacturing titanium implant materials. J Mater Sci: Mater Med. 2017; 28(3): 53. https://doi.org/10.1007/s10856-017-5863-1 